\section{Effect of El Niño-Southern Oscillation on the Number of Leaching Rain Events in Florida and Implications on Nutrient Management for Tomato}

\author{
Clyde W. Fraisse ${ }^{1,3}$, Zhengjun $\mathrm{Hu}^{1}$, and Eric H. Simonne ${ }^{2}$
}

ADDITIONAL INDEX wORDs. best management practices, ENSO, Solanum

lycopersicum, supplemental fertilizer application

Summary. Most of the winter vegetable production in the southeastern United States is located in Florida. High-value vegetable crops are grown under intensive fertilization and irrigation management practices using drip, overhead, or seepage irrigation systems. Rainfall events may raise the water table in fields irrigated by seepage irrigation resulting in leaching of nutrients when the level is lowered to remove excess water. The objective of this study was to assess the effect of El NiñoSouthern Oscillation (ENSO) phases on rainfall distribution and leaching rain occurrences during the fall, winter, and spring tomato (Solanum lycopersicum) growing seasons using long-term weather records available for main producing areas. Differences in fall growing season mean precipitation during El Niño, La Niña, and neutral years were found to be nonsignificant. Winter and spring mean precipitations during El Niño, La Niña, and neutral years were found to be significantly different. Winter and spring average rainfall amounts during La Niña and neutral years were lower than during El Niño years. During El Niño years, at least one leaching rainfall event of 1.0 inch or more in 1 day occurred at all locations and all planting seasons and two of these events occurred in more than 9 of 10 years except during the winter and spring planting seasons at the Tamiami Trail station located in Miami-Dade County. During the fall growing season of El Niño years, three to four 1.0 inch or more in 1-day leaching rainfalls may be expected at least 4 of 5 years at all locations. In the case of larger leaching rainfall events ( 3.0 inches or more recorded in 3 days or 4.0 inches or more recorded in 7 days), the probability of having at least one event was mostly less than 0.80 . Based on these results, nitrogen fertilizer supplemental applications of 30 to $120 \mathrm{lb} /$ acre could be applied during the fall growing season of all ENSO phases and during all planting seasons of El Niño years. Using current fertilizer prices, one supplemental fertilizer application of $30 \mathrm{lb} /$ acre nitrogen and $16.6 \mathrm{lb} /$ acre potassium costs \$55/acre. Assuming a median wholesale price of $\$ 12$ per $25-1 b$ box, this additional cost may be offset by a modest yield increase of 4.6 boxes/acre (compared with a typical $250025-1 b$ box/acre marketable yield). These results suggest that ENSO phases could be used to predict supplemental fertilizer needs for tomato, but adjustments to local weather conditions may be needed.

$\mathrm{F}$ lorida is among the wettest states in the United States with most areas receiving at least 50 inches of rain annually (Black, 1993). Most of the state of Florida lies within the extreme southern portion of the Northern Hemisphere humid subtropical climate zone, noted for its long hot and humid summers and mild and wet winters. The southernmost portion of the state is generally designated as belonging to the tropical savanna region. Sometimes also called the wet and dry tropics, tropical

\footnotetext{
${ }^{1}$ Agricultural and Biological Engineering Department, University of Florida, 271 Rogers Hall, P.O. Box 110570, Gainesville, FL 32611-0570

${ }^{2}$ Horticultural Sciences Department, University of Florida, Gainesville, FL 32611-0690

${ }^{3}$ Corresponding author. E-mail: cfraisse@ufl.edu.
}

savanna precipitation is highly concentrated in the warmer months (Winsberg, 2003). Fall in Florida is normally drier than summer because convectional rainstorms cease to be so frequent without the intense heating of the ground that occurs during summer. Also, the convergence of moist air masses from the Gulf of
Mexico and the Atlantic Ocean over the interior of the peninsula are not as strong as during the summer. However, fall is the season when heavy rains may occur in association with tropical cyclones. According to Winsberg (2003), during the last 30 years, $\approx 75 \%$ of all Florida weather stations reported at least $1 \mathrm{~d}$ in which at least 8 inches of rain fell, and $12 \%$ experienced such torrential storms four or more times. Almost half of these heavy rains occurred in September and October and were associated with tropical depressions. Conversely, spring in Florida is generally dry as a result of the weakness of two important mechanisms by which rainfall reaches the state. The polar jet stream rarely passes into the southernmost U.S. states causing frontal rainfall to become less frequent than during the winter. The other reason is that the stable air flowing from high-pressure systems over the Atlantic Ocean continues during the spring and reduces convectional and convergent rainfall.

The El Niño-Southern Oscillation (ENSO) phenomenon is the strongest driver of interannual climate variability around the world, including the southeastern United States (Fraisse et al., 2006). ENSO is a natural, coupled atmospheric-oceanic cycle that occurs in the tropical Pacific Ocean approximately every 2 to 7 years. When sea surface temperature (SST) in the eastern equatorial Pacific Ocean is higher than the long-term average (or "normal temperature"), the phenomenon is called El Niño. When the SST is lower than normal, the phenomenon is called La Niña. When the SST is normal, the event is called "neutral." In Florida, El Niño is expected to bring $30 \%$ to $40 \%$ more rainfall and cooler temperatures than normal during winter and spring, whereas La Niña is expected to bring a warmer and drier than normal winter and spring seasons. Indices such as SST indices, the Japan Meteorological

\begin{tabular}{llll}
\hline $\begin{array}{l}\text { Units } \\
\text { To convert U.S. to SI, } \\
\text { multiply by }\end{array}$ & U.S. unit & SI unit & $\begin{array}{l}\text { To convert SI to U.S., } \\
\text { multiply by }\end{array}$ \\
\hline 0.4047 & $\mathrm{acre}(\mathrm{s})$ & $\mathrm{ha}$ & 2.4711 \\
0.3048 & $\mathrm{ft}$ & $\mathrm{m}$ & 3.2808 \\
25.4 & inch(es) & $\mathrm{mm}$ & 0.0394 \\
0.4536 & $\mathrm{lb}$ & $\mathrm{kg}$ & 2.2046 \\
1.1209 & $\mathrm{lb} / \mathrm{acre}$ & $\mathrm{kg} \cdot \mathrm{ha}^{-1}$ & 0.8922 \\
0.9072 & ton $(\mathrm{s})$ & $\mathrm{mg}$ & 1.1023 \\
$\left({ }^{\circ} \mathrm{F}-32\right) \div 1.8$ & ${ }^{\circ} \mathrm{F}$ & ${ }^{\circ} \mathrm{C}$ & $\left(1.8 \times{ }^{\circ} \mathrm{C}\right)+32$
\end{tabular}


Agency (JMA) index, and the surface atmospheric pressure-based southern oscillation index (SOI) are used to define ENSO years or the strength, timing, and duration of ENSO events (Hanley et al., 2003).

Long-range seasonal forecasts over the southeastern United States (Southeast Climate Consortium, 2008) are derived from predicting the evolution of SST anomalies in the equatorial Pacific up to 1 year in advance (Black, 1993; Fraisse et al., 2004). Two general types of prediction models are currently used to predict SSTs. Dynamic models consist of a series of mathematical expressions that represent the physical laws governing the coupled ocean/atmosphere system. Dynamic models compute a forecast of ENSO conditions 6 months or more in advance based on the current conditions in the ocean and atmosphere, including ocean temperature profiles, turbulent processes in the atmospheric boundary layer, cloud physics, and solar and infrared (thermal) radiation. The second type of models called statistical models use long-term historical observations to make ENSO phases predictions (Tritel, 2005). ENSO prediction models, whether dynamic or statistical, alone and now often combined, are still imperfect, but they may be used to predict how ENSO may occur $\approx 1$ year in advance (Rosenzweig and Hillel, 2008).

Plants can be categorized by temperature hardiness or ability to withstand a certain range of minimum temperatures. USDA hardiness zones are regions defined by a $10^{\circ} \mathrm{F}$ difference in the average annual minimum temperature. Because most killing frosts prevent outdoor vegetable production in the late fall and winter in regions colder than the $8 \mathrm{~b}$ zone, where minimum temperatures vary within 15 to $20^{\circ} \mathrm{F}$, ENSO phases have a greater effect on crop production in southern Florida (regions 9a and 9b), where minimum temperatures vary within 20 to $30^{\circ} \mathrm{F}$. Most of the winter vegetable production in the southeastern United States is located in central Florida (mostly in Hillsborough and Manatee counties), southwestern Florida (mostly Lee, Hendry, and Collier counties), eastern coastal Florida (mostly Palm Beach County), and southern Florida (south MiamiDade County). High-value vegetable crops such as tomato, bell pepper (Capsicum annuum), snap bean (Phaseolus vulgaris), sweet corn (Zea mays), and celery (Apium graveolens) are grown under intensive fertilization and irrigation management using drip, overhead, or seepage irrigation systems (Olson and Simonne, 2007).

Seepage irrigation consists of maintaining an artificially higher water table above an impermeable soil layer found at the 0.9 - to $1.5-\mathrm{m}$ depth and is the most common irrigation system used for vegetable production on flatwoods spodic soils in Florida (Smajstrla et al., 1992). Ground water is pumped into canals and ditches and then moves horizontally between two adjacent ditches. When the waterfronts from two ditches meet, the water table rises, thereby irrigating the crop. Because of the impermeable layer and the canals that surround the fields, seepage-irrigated farms are like large pans. The water is confined, and rainfall events may raise the water table near or above the soil surface. Because vegetable crops are sensitive to flooding (Rao and Li, 2003), the water level needs to be promptly lowered by pumping excess water out of the farm after a large rainfall, thereby also removing some soluble nutrients from the root zone. In an attempt to compensate for these unintended nutrient losses and because of the long growing seasons, growers often use fertilization rates in excess of current University of FloridaInstitute of Food and Agricultural Sciences (UF-IFAS) recommendations (Cantliffe et al., 2006). As a response to the Federal Total Maximum Daily Load mandate described in the Federal Clean Water Act, the Florida legislature passed the Florida Watershed Restoration Act (Florida Senate, 1999), which gave the Florida Department of Agriculture and Consumer Services (FDACS) the authority to develop best management practices (BMPs). Adopted by reference in rule $5 \mathrm{M}-8$ of the Florida Administrative Code, the "Water quality/quantity best management practices for Florida vegetable and agronomic crops" manual is the document that describes the BMPs that apply to vegetable crops in Florida (FDACS, 2005). Because the manual recognizes UF-IFAS production recommendations as the base for related BMPs, it is essential that these recommendations are flexible and science-based to be trusted and widely adopted by the vegetable industry.

Weather patterns affect crop production and long-term seasonal forecasts may be used to adjust cultural practices. The marketable yield of watermelon (Citrullus lanatus) grown with seepage irrigation on an Immokalee fine sand significantly responded to a fertilizer rate $[265 \mathrm{lb} /$ acre nitrogen $(\mathrm{N}), 74 \mathrm{lb} /$ acre phosphorus $(\mathrm{P})$, $381 \mathrm{lb} /$ acre potassium $(\mathrm{K})]$ greater than the recommended rate $(150 \mathrm{lb} /$ acre $\mathrm{N}, 44 \mathrm{lb} /$ acre $\mathrm{P}, 125 \mathrm{lb} /$ acre K) only during a wet year $[38,640$ versus $\left.21,616 \mathrm{~kg} \cdot \mathrm{ha}^{-1}(P<0.05)\right]$ for the high versus recommended fertilizer rates (Hendricks et al., 2007). A study conducted in Australia using historical weather data, SOI, soil moisture at planting, and wheat (Triticum aestivum) and canola (Brassica napus) yield simulation from the APSIM model (Keating et al., 2003) demonstrated that the optimal $\mathrm{N}$ rate for these crops was different for the different ENSO phases (Wang et al., 2008). However, the economical risk of yield (and revenue) loss during low-yielding years was not offset by the probability of yield (and revenue) increase during high-yielding years for these low-value crops. Hansen et al. (1999) found that ENSO phase and season interacted to significantly influence quarterly yields, prices, and production of tomato, bell pepper, sweet corn, and snap beans in Florida. Yields of tomato, bell pepper, sweet corn, and snap bean were lower and prices of bell pepper and snap bean were higher during El Niño than during neutral or La Niña years. Production of tomatoes was higher during La Niña years. They suggested that the yield response could be the result of increased rainfall, reduced daily maximum temperatures, and reduced solar radiation during El Niño winters. The link between ENSO phases and weather patterns may warrant adjustments in production practices, especially those affected by rainfall. These include planting date, irrigation rate, and fertilization rate. Because in Florida, vegetable crops are planted at regular intervals and seepage irrigation is used, water table management and fertilization practices could be adjusted (Olson and Simonne, 2007). Using current production recommendations and historical weather data, we wanted to determine if a low probability of 
rainfall during a known ENSO phase would warrant a reduction in current fertilizer rates used for commercial tomato production (as a response to a low probability of leaching rainfall occurrence) and, conversely, if a high probability in leaching rain occurrence would justify an increase in fertilization recommendation. Ultimately, as illustrated in the wheat and canola simulation (Wang et al., 2008), this type of production decision also needs to consider the associated costs of fertilization.

\section{Materials and methods}

TOMATO GROWING SEASONS IN Florida. Because of its economic importance, round tomato was the model crop used in this study. In 2007 , in terms of total value of production, Florida accounted for $36 \%$ of the total U.S. value for fresh market tomatoes ( $\$ 464$ million), and a total of 38,200 acres were planted with main producing areas being Hillsborough, Manatee, Hendry, Collier, and Miami-Dade counties (FDACS, 2008). Tomatoes are planted continuously between August and February in southern Florida, and growing seasons for tomatoes were defined as fall, winter, and spring for planting dates between 15 Aug. and 15 Oct., 16 Oct. and 15 Dec., and 16 Dec. and 15 Feb., respectively (Ozores-Hampton et al., 2006). Typical lengths of growing season for tomato are 18, 20, and 16 weeks for fall, winter, and spring, respectively. According to Cantliffe et al. (2006), fertilizer rates used for seepage-irrigated tomato range between 250 and $350 \mathrm{lb} /$ acre. Current statewide UF-IFAS fertilization recommendation for tomato grown in Florida and planted on 6.0 -ft centers is a base rate of $200 \mathrm{lb} /$ acre N. A supplemental application of $30 \mathrm{lb} /$ acre $\mathrm{N}$ and $16.6 \mathrm{lb} /$ acre $\mathrm{K}$ is allowed after a leaching rain, during extended harvest seasons, or when crop nutritional status has been diagnosed as "low" or "insufficient" based on petiole sap testing or foliar analysis (Olson et al., 2007). Because supplemental fertilizer applications need to be made with a fertilizer injection wheel that punches holes into the plastic and require an additional trip in the field resulting in increased cost of production, growers prefer to use fertilizer rates in excess of the recommended rates to prevent nutrient shortage and avoid applications costs of supplemental fertilization. Assuming an average application rate of $300 \mathrm{lb} /$ acre, the $100 \mathrm{lb} /$ acre $\mathrm{N}$ above the UF-IFAS rate typically used by growers could be viewed as a "preventive" supplemental application of $\mathrm{N}$ for approximately three leaching rainfall events $(3 \times 30=90 \mathrm{lb} /$ acre $)$. Recommendations for $\mathrm{P}, \mathrm{K}$, and $\mathrm{mi}$ cronutrients applications are based on soil test results (Olson et al., 2007).

LEACHING RAINFALL EVENTS. The UF-IFAS (Simonne and Hochmuth, 2007 ) and BMP (FDACS, 2005) define leaching rains as rainfall amounts of 3 inches or more recorded in $3 \mathrm{~d}$ or 4 inches or more recorded in $7 \mathrm{~d}$. Although consensus exists that such rains represent leaching events on Florida's sandy soils (Cantliffe et al., 2006), research on water table depth response to rainfall for an Immokalee fine sand showed that 1 inch rainfall recorded in $1 \mathrm{~d}$ resulted in a raising of the water table by 16 inches (Jaber and Shukla, 2006). Consequently, a $\mathrm{l}$-inch or more rainfall event in $1 \mathrm{~d}$ may also result in nutrient leaching, especially at the beginning of the

\section{Hillsborough County}
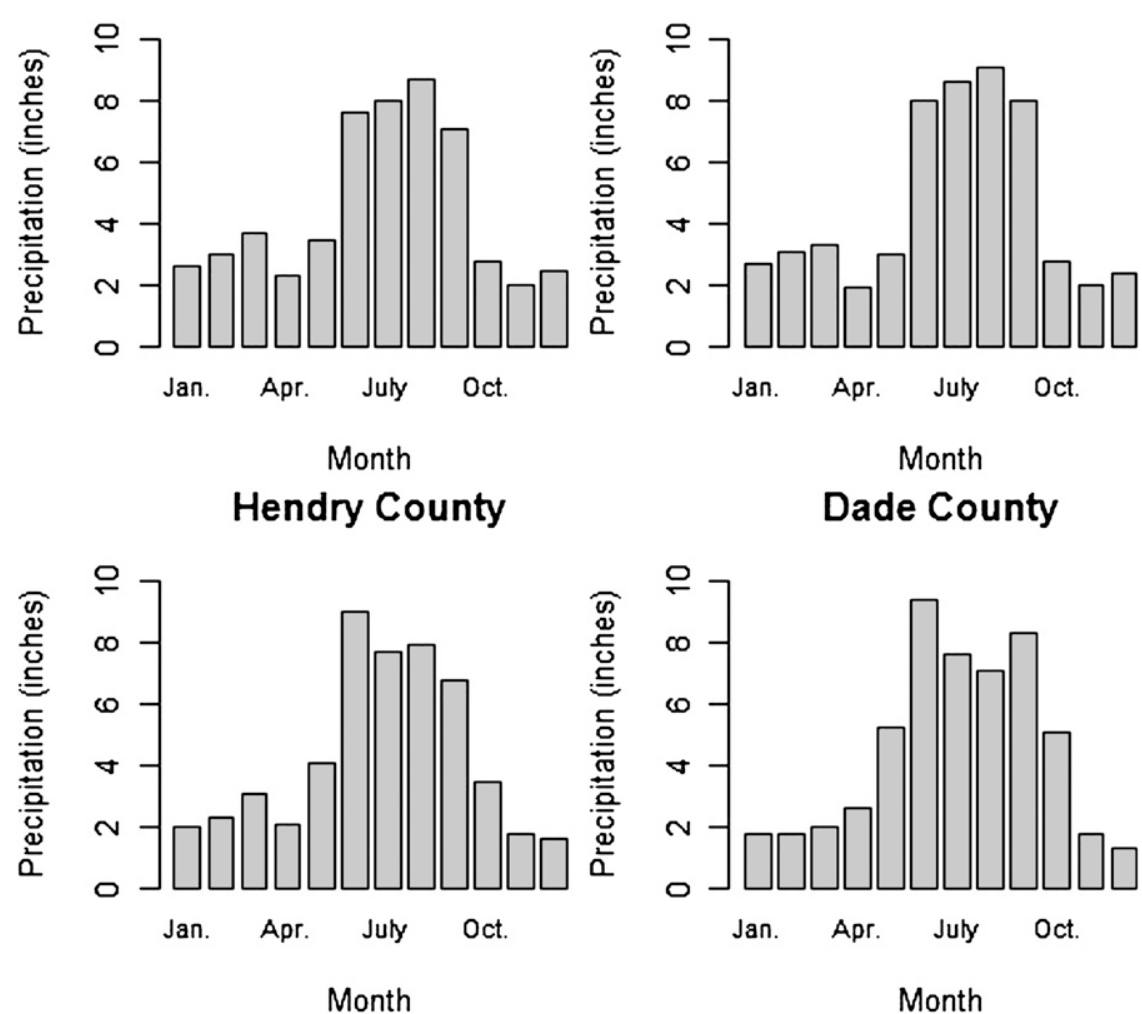

Fig. 1. Long-term average monthly rainfalls (inches) for Hillsborough, Manatee, Hendry, and Miami-Dade counties in Florida; 1 inch $=25.4 \mathrm{~mm}$. season when the water table is kept near the 14-inch depth as a result of limited rooting depth and most the fertilizer is still present in the bed (Cantliffe et al., 2006). This expanded definition of a leaching rainfall was included in UF-IFAS recommendations for vegetable crops in 2007.

The approach used in this study was to analyze the number of leaching rainfall events using long-term precipitation records compiled from the National Weather Service's Cooperative Observer Network (NCDC TD 3200 ) of four weather stations: Plant City, Hillsborough County (lat. $28^{\circ} 01^{\prime} \mathrm{N}$, long. $\left.81^{\circ} 09^{\prime} \mathrm{W}\right)$, Parrish, Manatee County (lat. 26 $37^{\prime} \mathrm{N}$, long. $82^{\circ} 21^{\prime}$ W), La Belle, Hendry County (lat. $26^{\circ} 45^{\prime} \mathrm{N}$, long. $81^{\circ} 26^{\prime}$ W), and Tamiami Trail, Miami-Dade County (lat. $25^{\circ} 46^{\prime} \mathrm{N}$, long. $80^{\circ} 49^{\prime}$ $\mathrm{W})$. Although seepage irrigation is not used to irrigate crops in MiamiDade County, the Tamiami Trail weather station was included in this study to represent the climate of the southernmost region of Florida because high water table conditions 
Plant City, Hillsborough County - Fall
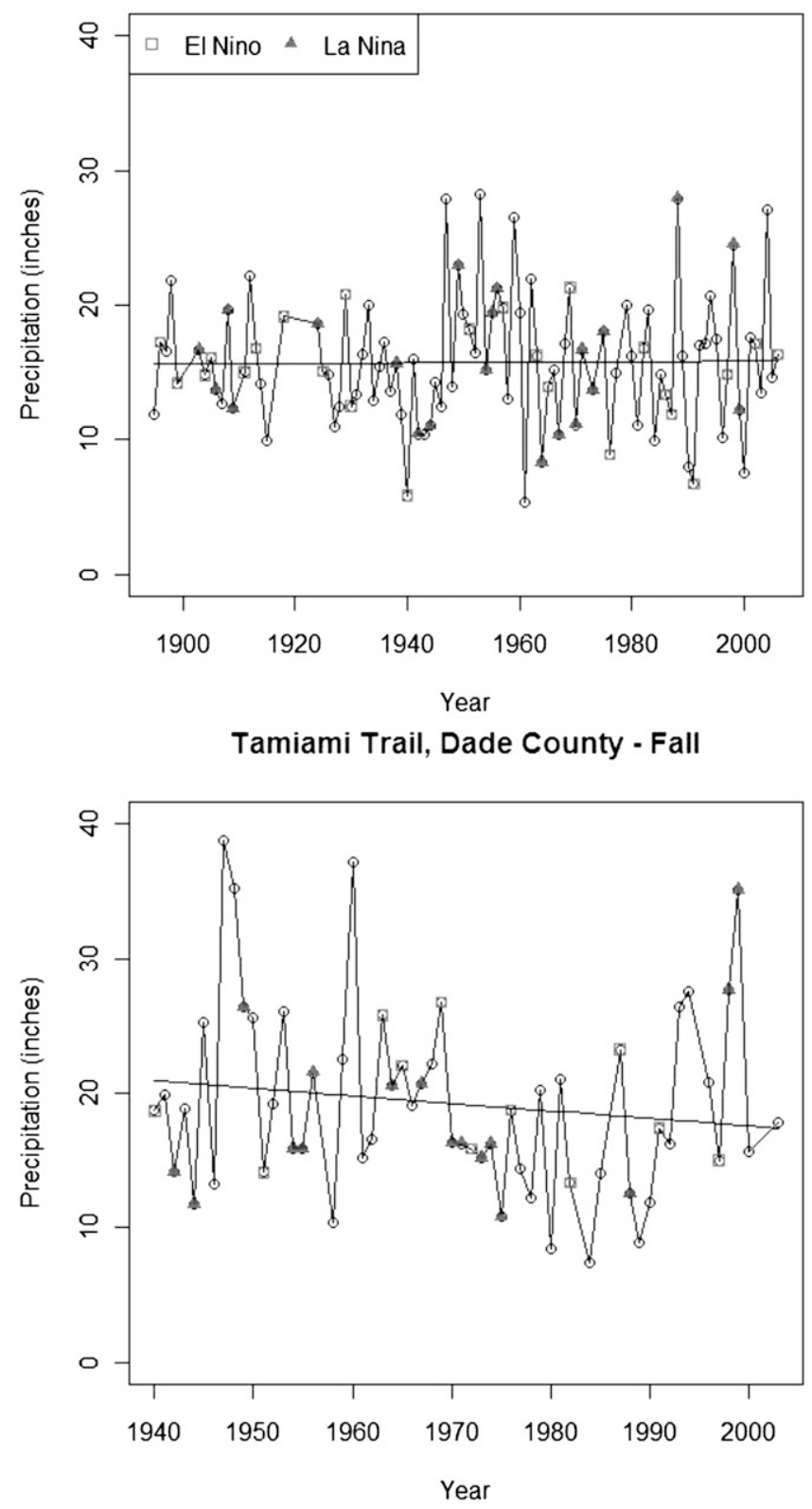

Fig. 2. Total rainfall observed during the fall growing season at the Plant City (top) and Tamiami Trail (bottom) weather stations in Florida (open squares indicate El Niño growing seasons and solid triangles indicate La Niña seasons); 1 inch $=25.4 \mathrm{~mm}$.

resulting from extreme rainfall events are also a concern to growers in that county. Weather observations contained daily values of maximum and minimum temperatures and precipitation for a period of record of at least 50 years ending in Dec. 2006. The minimum, mean, maximum, and $\mathrm{SD}$ of total precipitation amounts observed at each weather station were calculated for each planting season and ENSO phase. The JMA index was used to categorize ENSO phases. JMA defines a warm (El Niño) event as a consecutive 6-month period, including October, November, and December, in which SST anomalies, based on the 1971-2000 reference period, are greater than $0.5^{\circ} \mathrm{C}$. A cold event (La Niña) is defined when anomalies during the same time period are less than $0.5^{\circ} \mathrm{C}$. A linear regression was used to describe long-term rainfall trends for each station and growing season combination. Duncan's multiple range tests were used to separate precipitation means during each ENSO phase and growing season at the $0.05 P$ level. Precipitation residuals were calculated for each year and growing season by subtracting the expected precipitation amount for year, $y$ $\left(E P_{y}\right)$, from the observed rainfall in the same year $\left(O P_{y}\right)$. Relative residuals $\left(R R_{y}\right)$, defined as the ratio (\%) of residuals to expected precipitation amounts (Eq. 1), were computed to facilitate the comparison and analysis of ENSO influences on precipitation amounts.

$$
R R_{\Upsilon}=\frac{O P_{\Upsilon}-E P_{\Upsilon}}{E P} * 100
$$

The historical occurrences of leaching rain events defined as 1 inch or more in $1 \mathrm{~d}$ (" $1 \mathrm{~d}$ " leaching rainfall), 3 inches or more in $3 \mathrm{~d}$ (" $3 \mathrm{~d}$ "), and 4 inches or more in $7 \mathrm{~d}$ ("7 d") were counted and analyzed for each station for periods of 18,20 , and 16 weeks beginning on simulated tomato planting dates of 15 Aug., 16 Oct., and $15 \mathrm{Dec}$. The qualifiers $1 \mathrm{~d}, 3 \mathrm{~d}$, and $7 \mathrm{~d}$ were used to conveniently refer to the three types of leaching rain events and do not necessarily imply an increasing risk of nutrient leaching. The running totals of rainfall and days were reset to 0 each time a qualifying leaching rainfall event occurred. The frequencies with which each leaching rain category occurred during each planting season and ENSO phase were tabulated. The frequency and exceedance probabilities were calculated for each planting season, leaching rain category, and ENSO phase. The probability of exceedance indicates the likelihood that the number of leaching rains during the growing season will exceed a given number of occurrences varying from one to 10 in the case of the 1 - $\mathrm{d}$ leaching rains and from one to five for the 3-d and 7-d leaching rains. Statistical analysis of the difference between two populations' proportions or probabilities was conducted to determine if the probabilities of exceeding leaching rainfall events were significantly different for El Niño and La Niña years at the $1 \%$ and $5 \%$ probability levels (Daniel, 1995). When expressed in terms of years, long-term probability values of 0.80 and 0.50 mean that $P$ is exceeded 8 and 5 years out of 10 , respectively. The threshold risks of $P=0.80$ and $P=1.00$ were selected to represent the lowest probability of exceedance for justifying 
Plant City, Hillsborough County - Winter

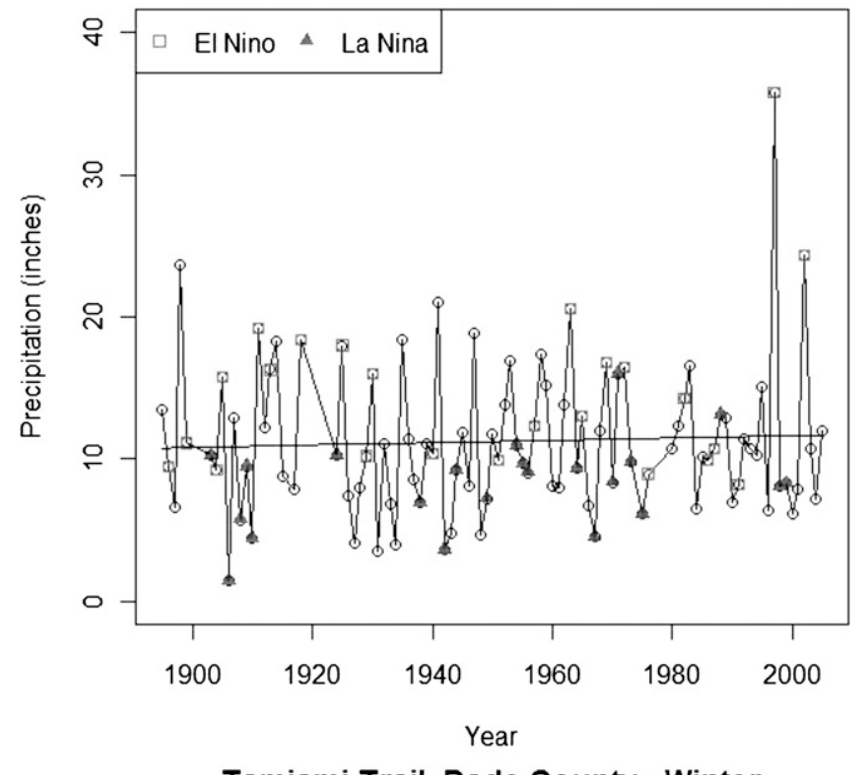

Tamiami Trail, Dade County - Winter

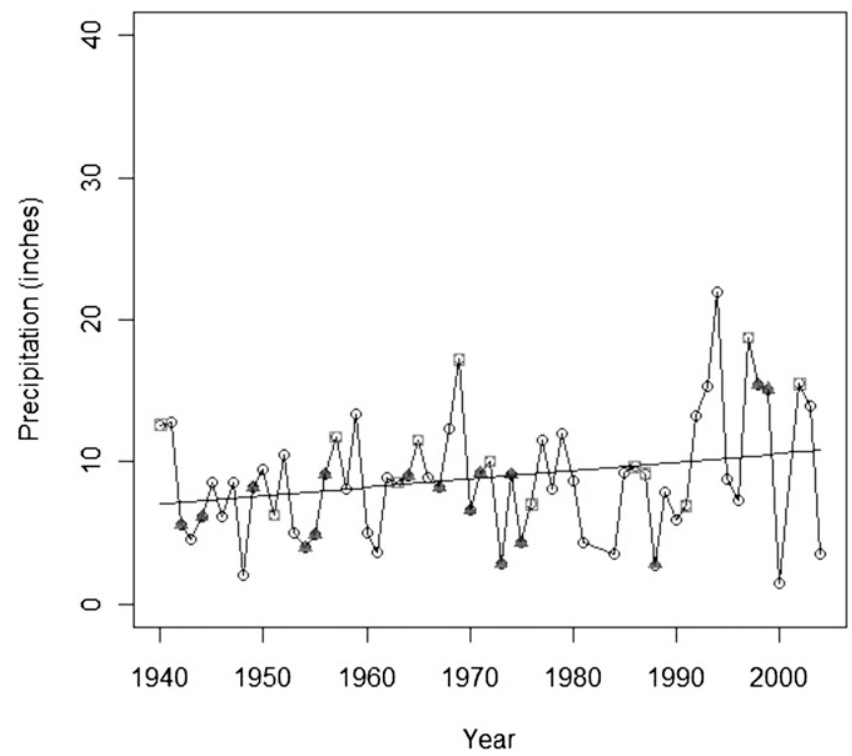

Fig. 3. Total rainfall observed during the winter growing season at the Plant City (top) and Tamiami Trail (bottom) weather stations in Florida (open squares indicate El Niño growing seasons and solid triangles indicate La Niña seasons); 1 inch $=25.4 \mathrm{~mm}$.

a supplemental fertilizer application from a strict and flexible environmental protection standpoint (correct application 4 years out of 5 and 5 years out of 5$)$, respectively. A threshold risk of $P=0.50$ was selected to represent the business (economical) risk of making an unnecessary supplemental fertilizer application 1 year out of 2 . It is currently not possible to directly compare the environmental and business risks. by the International Research Institute for Climate and Society and reported by the Southeast Climate Consortium (2008) can be used to forecast ENSO phases up to 1 year in advance. The effective application of seasonal climate forecast in general and ENSO phase forecast in particular requires making a decision that takes a probabilistic forecast into account (Fraisse et al., 2006). When the probability of exceedance was greater than 0.80 , climate-adjusted $\mathrm{N}$ fertilization practices were calculated based on ENSO phase forecast and associated leaching rain events probabilities for a given growing season. The most commonly used fertilizers for tomato are ammonium nitrate and potassium sulfate. The change in production cost resulting from a supplemental fertilizer application was calculated using $\$ 740 / \mathrm{Mg}$ for ammonium nitrate and $\$ 1400 / \mathrm{Mg}$ for potassium sulfate quoted in Oct. 2008 for bulk delivery.

\section{Results and discussion}

RAINFALL PATTERNS. For all selected weather stations, June, July, August, and September (the two latter in the tomato fall planting season) were the wettest months of the year (Fig. 1). Monthly rainfall totals decreased for the fall, winter, and spring seasons. Winter and spring seasons in the two southern most counties, Hendry and Miami-Dade, were drier than in Hillsborough and Manatee counties located further north in the peninsula, highlighting the fact that rainfall patterns in the southern most region of the state are characterized as wet and dry tropics and less impacted by frontal rainfall systems during the winter.

The number of El Niño (La Niña) years recorded varied from 13 (14) at the Parrish station to 25 (25) at the Plant City station for which a longer period of records is available. Figures 2 to 4 show the total precipitation amounts observed at selected stations during fall, winter, and spring growing seasons. Visual inspection of long-term precipitation trends during the fall growing season (Fig. 2) indicates a slight decrease at the Tamiami Trail station (Miami-Dade County) but no detectable trend at the Plant City station (Hillsborough County). Figure 3 shows total precipitation amounts for the same stations but during the winter growing season. In this case, a slight total rainfall 
increase over time can be observed at the Tamiami Trail station. Figure 4 shows total precipitation amounts observed during the spring growing season at the Plant City and La Belle (Hendry County) stations. A slight increase of total rainfall over time can be observed in both stations.

Average precipitation ranged from 4.8 inches during La Niña spring seasons in Miami-Dade County to 19.6 inches during neutral fall seasons (Table 1). Average precipitation amounts were higher during the fall growing season than during the winter or spring seasons independent of the ENSO phase. Duncan's test results indicated that precipitation means during the fall growing season are not significantly different $(P<0.05)$ during El Niño, La Niña, and neutral phases, with the exception of La Niña years at the La Belle station. However, El Niño precipitation means during the winter growing season are significantly different from La Niña and neutral years in all stations but the Tamiami Trail station, where it was

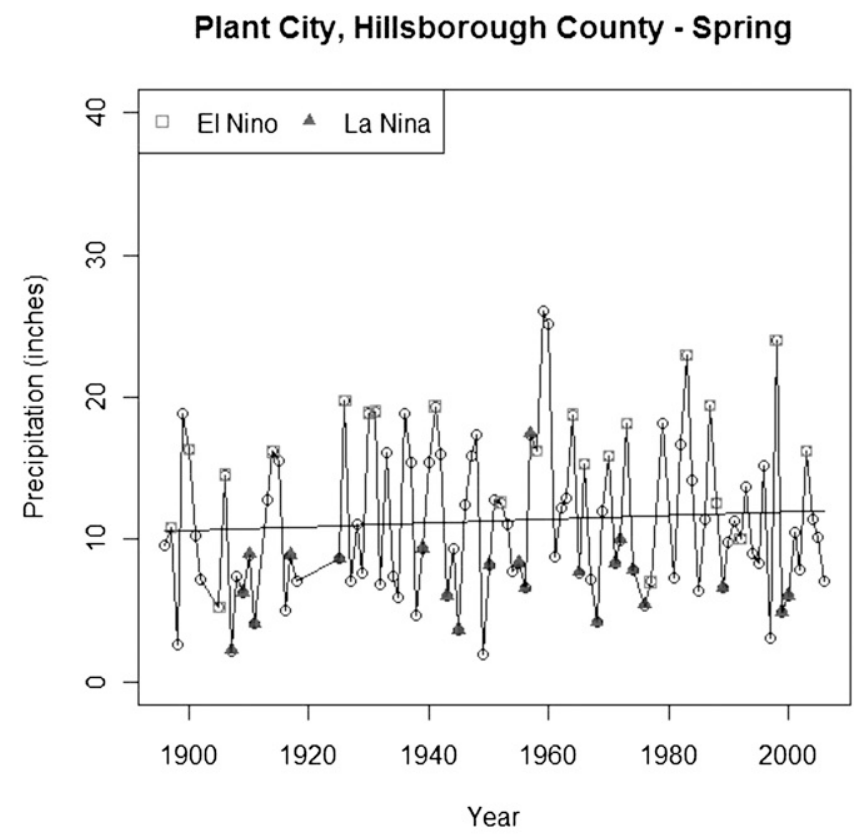

La Belle, Hendry County - Spring

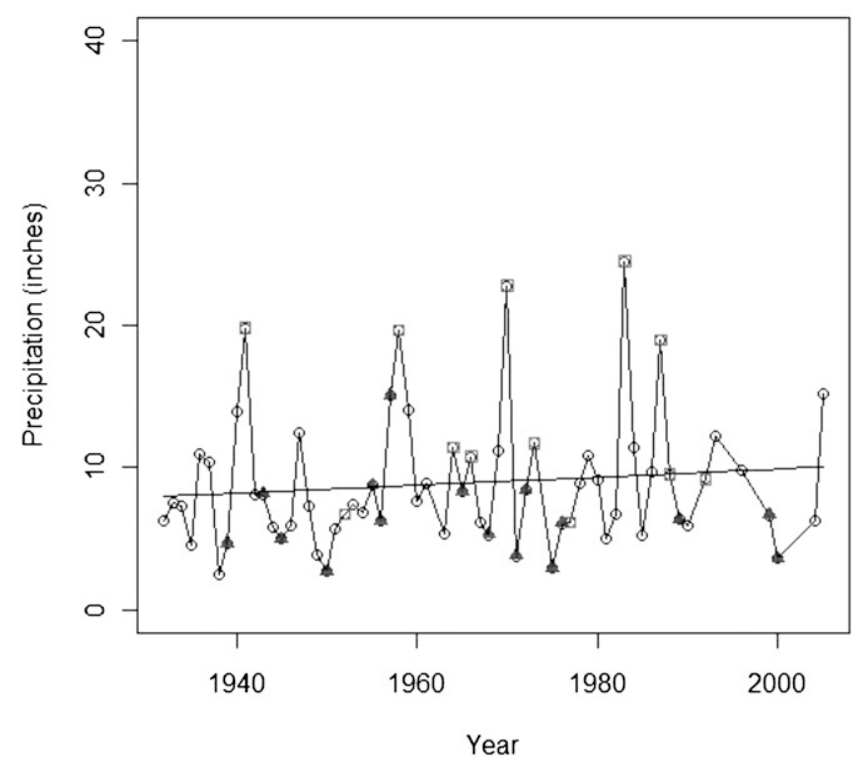

Fig. 4. Total rainfall observed during the spring growing season at the Plant City (top) and La Belle (bottom) weather stations in Florida (open squares indicate El Niño growing seasons and solid triangles indicate La Niña seasons); 1 inch $=25.4 \mathrm{~mm}$.

grouped together with neutral years. Spring precipitation means during El Niño years are also significantly different from La Niña and neutral years at the two southernmost stations ( $\mathrm{La}$ Belle and Tamiami Trail). In the case of the Plant City and Parrish stations, precipitation means during the spring growing season are significantly different for all ENSO phases. These results confirm the general knowledge that precipitation amounts during La Niña and neutral years are generally lower than during El Niño years, but primarily during the winter and spring seasons and not so much during the fall growing season. Except for the La Belle station, average rainfall during the fall growing season was higher during neutral years than during $\mathrm{El}$ Niño years. The maximum rainfall amounts observed during the fall growing season were 29.3, 28.2, 28.2, and 38.8 inches for La Belle, Parrish, Plant City, and Tamiami Trail stations, respectively, and occurred during neutral years. During the winter growing season, maximum observed rainfall amounts occurred during El Niño years in all stations, except at the Tamiami Trail station where the maximum rainfall amount was observed during a neutral year. During the spring growing season, maximum amounts were also observed during El Niño years at the La Belle, Parrish, and Tamiami Trail stations but during a neutral year at the Plant City station.

A positive (or negative) relative residual indicated that the amount of precipitation observed during a growing season was above (or below) the long-term trend line (Table 2). During the winter and spring growing seasons, calculated El Niño relative residuals were positive for all stations, ranging from $24.5 \%$ for the Tamiami Trail station during the winter growing season to $57.6 \%$ for the La Belle station also during the winter growing season. Calculated winter and spring residuals during La Niña years were negative for all stations, ranging from $-14.2 \%$ for the Tamiami Trail station (winter growing season) to $-43.4 \%$ for the Parrish station (spring growing season). No clear trend was observed during the fall growing season. Calculated relative residuals for growing seasons during El Niño years ranged from $-3.7 \%$ to $10.1 \%$ and were positive for three stations and 
Table 1. Basic statistics for total precipitation during the fall, winter, and spring growing seasons at four weather stations in Florida during different El Niño Southern Oscillation (ENSO) phases (neutral, El Niño, and La Niña).

\begin{tabular}{|c|c|c|c|c|c|c|c|c|c|c|c|c|}
\hline \multirow{3}{*}{$\begin{array}{l}\text { ENSO } \\
\text { phase }\end{array}$} & \multicolumn{4}{|c|}{ Fall season } & \multicolumn{4}{|c|}{ Winter season } & \multicolumn{4}{|c|}{ Spring season } \\
\hline & Minimum $^{\mathrm{z}}$ & Mean & Maximum $^{\mathrm{y}}$ & $\overline{S D}$ & Minimum & Mean & Maximum & $\overline{S D}$ & $\overline{\text { Minimum }}$ & Mean & Maximum & $\overline{\mathrm{SD}}$ \\
\hline & \multicolumn{4}{|c|}{ (inches) $^{\mathrm{x}}$} & \multicolumn{4}{|c|}{ (inches) } & \multicolumn{4}{|c|}{ (inches) } \\
\hline & & & Plant City & Hills & borough Cou & ty-Peri & of records: & $896-2$ & 006 & & & \\
\hline Neutral & 5.4 & $15.8 \mathrm{a}^{\mathrm{w}}$ & 28.2 & 5.0 & 3.5 & $10.9 \mathrm{~b}$ & 23.6 & 4.6 & 1.9 & $11.1 \mathrm{~b}$ & 26.0 & 5.1 \\
\hline El Niño & 5.9 & $15.1 \mathrm{a}$ & 21.3 & 3.9 & 8.2 & $14.8 \mathrm{a}$ & 35.8 & 6.2 & 5.2 & $15.9 \mathrm{a}$ & 24.0 & 4.7 \\
\hline La Niña & 8.3 & $16.2 \mathrm{a}$ & 27.9 & 5.2 & 1.4 & $8.3 \mathrm{~b}$ & 16.0 & 3.2 & 2.2 & $7.2 \mathrm{c}$ & 17.4 & 3.1 \\
\hline El Niño & 7.6 & $18.2 \mathrm{a}$ & 25.3 & 5.4 & 8.8 & $17.0 \mathrm{a}$ & 37.4 & 8.5 & 6.1 & $16.4 \mathrm{a}$ & 27.1 & 5.9 \\
\hline La Niña & 6.8 & $15.1 \mathrm{a}$ & 28.1 & 6.2 & 3.7 & $8.2 \mathrm{~b}$ & 14.2 & 3.7 & 2.9 & $6.4 \mathrm{c}$ & 13.2 & 3.1 \\
\hline \multicolumn{13}{|c|}{ La Belle, Hendry County-Period of records: 1932-2004 } \\
\hline Neutral & 8.3 & $16.7 \mathrm{a}$ & 29.3 & 5.4 & 2.9 & $9.1 \mathrm{~b}$ & 13.8 & 2.8 & 2.5 & $8.2 \mathrm{~b}$ & 15.2 & 3.1 \\
\hline El Niño & 11.4 & $17.0 \mathrm{a}$ & 25.2 & 4.5 & 7.5 & $12.6 \mathrm{a}$ & 17.4 & 3.0 & 6.1 & $14.3 \mathrm{a}$ & 24.5 & 6.4 \\
\hline El Niño & 13.4 & $19.2 \mathrm{a}$ & 26.8 & 4.7 & 6.2 & $11.1 \mathrm{a}$ & 18.7 & 4.0 & 5.9 & $10.7 \mathrm{a}$ & 19.5 & 4.6 \\
\hline La Niña & 10.8 & $18.6 \mathrm{a}$ & 35.1 & 6.5 & 2.8 & $7.5 \mathrm{~b}$ & 15.4 & 3.8 & 1.4 & $4.8 \mathrm{~b}$ & 9.2 & 2.1 \\
\hline
\end{tabular}

${ }^{2}$ Minimum total precipitation observed during the period of records.

Maximum total precipitation observed during the period of records.

${ }^{\mathrm{x}} \mathrm{l}$ inch $=25.4 \mathrm{~mm}$.

"Any two means within a column not followed by the same letter are significantly different by Duncan's test at $P \leq 0.05$.

Table 2. Average relative precipitation residuals, defined as the ratio of residuals to expected precipitation amounts during different El Niño-southern Oscillation (ENSO) phases (neutral, El Niño, and La Niña) and growing seasons at four weather stations in Florida.

\begin{tabular}{|c|c|c|c|c|}
\hline \multirow[b]{2}{*}{ Weather station } & \multirow[b]{2}{*}{ ENSO phase } & \multicolumn{3}{|c|}{ Avg relative precipitation residual (\%) } \\
\hline & & Fall & Winter & Spring \\
\hline \multirow[t]{2}{*}{ Plant City, Hillsborough County } & El Niño & -3.7 & 31.8 & 40.1 \\
\hline & Neutral & 0.6 & -3.4 & -1.7 \\
\hline \multirow[t]{2}{*}{ Parrish, Manatee County } & El Niño & 2.5 & 44.4 & 46.0 \\
\hline & La Niña & -13.7 & -28.4 & -43.4 \\
\hline \multirow{2}{*}{ La Belle, Hendry County } & La Niña & -18.9 & -28.3 & -23.8 \\
\hline & Neutral & 4.9 & -6.6 & -0.5 \\
\hline \multirow[t]{3}{*}{ Tamiami Trail, Miami-Dade County } & El Niño & 1.6 & 24.5 & 52.6 \\
\hline & La Niña & 0.5 & -14.2 & -30.4 \\
\hline & Neutral & -3.3 & -2.6 & -4.6 \\
\hline
\end{tabular}

negative for one (Plant City). For growing seasons during La Niña years, calculated relative residuals were positive for two stations and negative for the other two, ranging from $-18.9 \%$ (La Belle) to $2.8 \%$ (Plant City). We can speculate that the occurrence of La Niña fall growing seasons with precipitation amounts above the expected trend value is the result of higher probability for hurricanes and tropical storms to land in Florida during La Niña years than during El Niño years.
Potential Leaching Rainfall EVENTS. For l-d leaching rain events, probabilities of exceedance distributions were found to vary within a narrow range at all weather stations with a North to South trend (Table 3). This trend may be in response to the polar jet stream rarely passing into the southernmost areas of the state causing frontal rainfall to become less frequent traveling south from the Plant City to the Tamiami Trail stations. Also, probabilities of exceedance distributions for all years were within the same range as those for neutral years. Historical records showed that at least one 1-d leaching rainfall may be expected with certainty $(P=1.00)$ during all years in the fall growing season and during the El Niño years of all planting seasons at the Plant City, Parish, and La Belle weather stations. From a strict environmental risk of nutrient leaching, this supports a single supplemental fertilizer application in these two cases. Probabilities of exceedance were found to be 
Table 3. Probability of exceedance of having at least the specified number of leaching events of $1.0 \mathrm{inch}(25.40 \mathrm{~mm})$ or more in $1 \mathrm{~d}$ for the fall, winter, and spring planting seasons for different El Niño-southern Oscillation (ENSO) phases (neutral, El Niño, and La Niña) and all years at four weather stations in Florida.

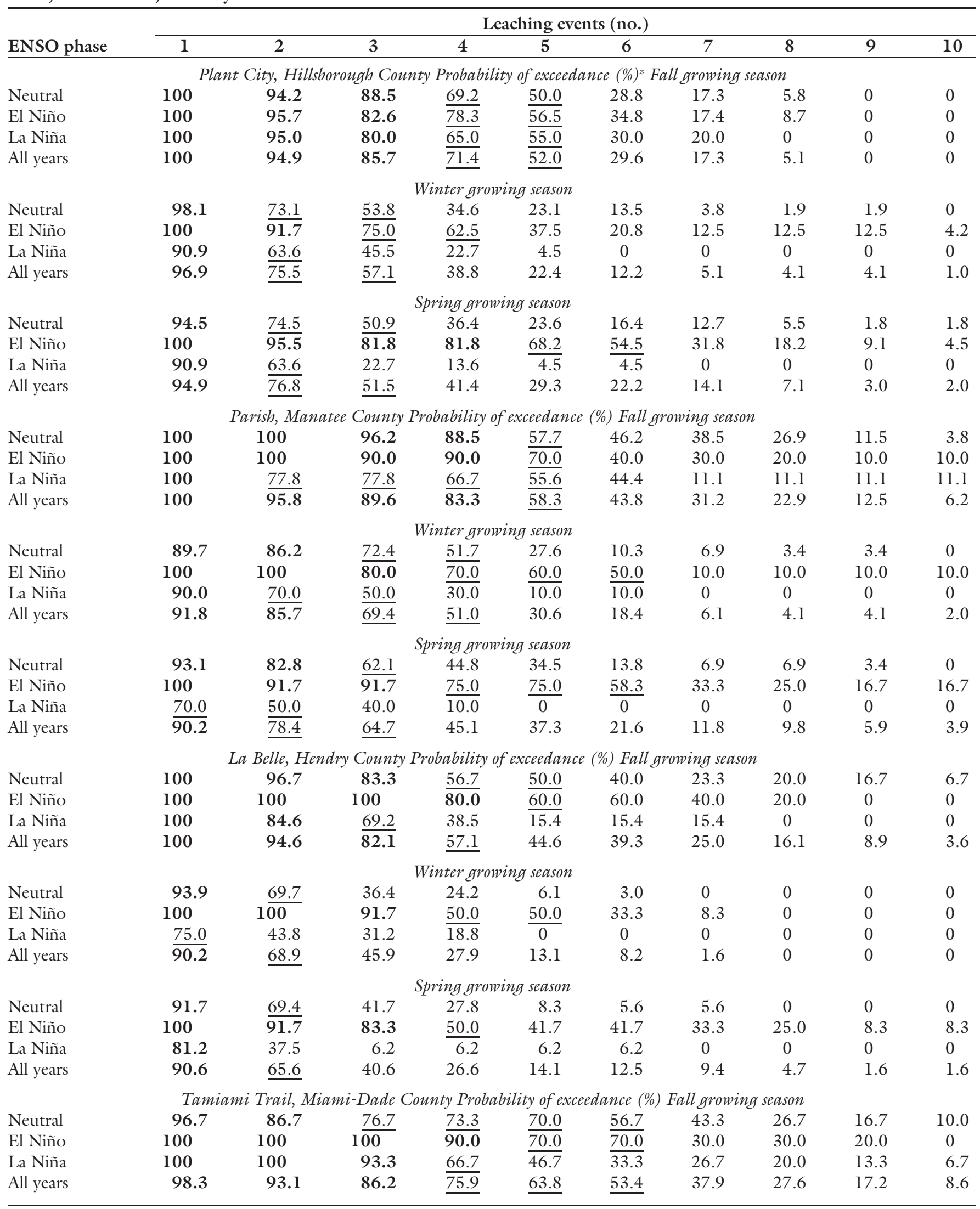


Table 3. (Continued) Probability of exceedance of having at least the specified number of leaching events of 1.0 inch (25.40 $\mathrm{mm}$ ) or more in $1 \mathrm{~d}$ for the fall, winter, and spring planting seasons for different El Niño-southern Oscillation (ENSO) phases (neutral, El Niño, and La Niña) and all years at four weather stations in Florida.

\begin{tabular}{|c|c|c|c|c|c|c|c|c|c|c|}
\hline \multirow[b]{2}{*}{ ENSO phase } & \multicolumn{10}{|c|}{ Leaching events (no.) } \\
\hline & 1 & 2 & 3 & 4 & 5 & 6 & 7 & 8 & 9 & 10 \\
\hline \multicolumn{11}{|c|}{ Winter growing season } \\
\hline El Niño & 92.3 & $\overline{76.9}$ & 38.5 & 30.8 & 23.1 & 15.4 & 7.7 & 0 & 0 & 0 \\
\hline La Niña & 81.2 & $\underline{62.5}$ & 31.2 & 6.2 & 0 & 0 & 0 & 0 & 0 & 0 \\
\hline All years & 83.9 & $\overline{62.9}$ & 37.1 & 17.7 & 11.3 & 8.1 & 1.6 & 0 & 0 & 0 \\
\hline \multicolumn{11}{|c|}{ Spring growing season } \\
\hline Neutral & 71.0 & 38.7 & 22.6 & 12.9 & 3.2 & 0 & 0 & 0 & 0 & 0 \\
\hline El Niño & $1 \overline{00}$ & $\underline{58.3}$ & 33.3 & 33.3 & 8.3 & 8.3 & 8.3 & 8.3 & 0 & 0 \\
\hline La Niña & $\underline{62.5}$ & $\overline{31.2}$ & 12.5 & 0 & 0 & 0 & 0 & 0 & 0 & 0 \\
\hline All years & $\overline{74.6}$ & 40.7 & 22.0 & 13.6 & 3.4 & 1.7 & 1.7 & 1.7 & 0 & 0 \\
\hline
\end{tabular}

${ }^{2}$ Probabilities of exceedance $P \geq 0.80$ are in bold; $0.80>P \geq 0.50$ are underlined.

significantly different between El Niño and La Niña years primarily during the winter and spring growing seasons (Table 3 ).

At the Plant City station, having at least three $1-\mathrm{d}$ leaching rains during the fall growing season had $P>0.80$ (occurrence 4 years out of 5 ) in all ENSO phases. In the winter growing season, the occurrence of a single leaching rain had $P>0.80$, except during El Niño years when at least two could be expected with $P>0.80$. In the spring growing season, up to four leaching rains could be expected with $P>0.80$ during El Niño years. Probabilities of having at least two to eight $\mathrm{l}-\mathrm{d}$ leaching rainfalls at the Plant City station in the winter and spring of La Niña years are lower and significantly different of El Niño years. Probability distributions at the Parish station were similar to the Plant City station with markedly reduced exceedance probabilities in $\mathrm{La}$ Niña years. In all three growing seasons, the probability of at least two leaching rains occurring were significantly different during El Niño and La Niña years and greater than $80 \%$ during El Niño years, whereas only at least one leaching rain in the fall and winter and none in the spring could be expected with a $P>0.80$ during $\mathrm{La}$ Niña years.

At the La Belle station, at least four 1 -d leaching rains in the fall and three in the winter and spring growing seasons may be expected with $P>$ 0.80 during El Niño years. Probabilities of at least three, four, five, and six leaching rain events occurring during El Niño and La Niña years were found to be significantly different during the fall, winter, and spring growing seasons. During La Niña years, at least two l-d leaching rains in the fall, zero in the winter, and one in the spring could be expected with $P>0.80$. The probability of having at least one $1-\mathrm{d}$ leaching rain during the winter planting season of La Niña years was 0.75 . At the Tamiami Trail weather station, the probability of having at least four 1 -d leaching rain events was greater than 0.80 during the fall growing season of El Niño years. In the winter planting season, the probability of exceedance was greater than 0.80 for a single $\mathrm{l}$-d leaching rainfall event for all ENSO phases. In the spring growing season, the probability of having at least one $1-\mathrm{d}$ leaching rainfall was greater than 0.80 only during El Niño years. Probability differences between El Niño and La Niña years were found to be not significantly different in most cases, but results could have been affected by the reduced sample size available for this station.

In summary, historical weather data show that one 1-d leaching rainfall will occur at all locations and all planting seasons more than 3 years out of 5, and at least two 1 -d leaching rainfalls will occur $(P>0.80)$ during all the growing seasons of El Niño years, except during winter and spring seasons at the Tamiami Trail station. During the fall growing season of El Niño years, at least three to four $1-\mathrm{d}$ leaching rainfalls may be expected with $P>0.80$ at all locations. These results show that ENSO phases could be used to adjust fertilizer applications relative to the 1 -d leaching rainfall events.

Overall, the probabilities of exceedance of the $3-\mathrm{d}$ (3 inches or more recorded in $3 \mathrm{~d}$ ) and $7-\mathrm{d}$ (4 inches or more recorded in $7 \mathrm{~d}$ ) leaching rains were much smaller than those of the $\mathrm{l}-\mathrm{d}$ leaching rains and not significantly different between El Niño and La Niña years (Table 4). This suggests that a large proportion of $1-\mathrm{d}$ leaching rainfall events may not be associated with tropical storms or hurricanes. No probability of exceedance of 1.00 was found for $3-\mathrm{d}$ and $7-\mathrm{d}$ leaching rains. The probability of having at least one 3 -d leaching rain was equal or greater than $80 \%(P \geq 0.80)$ only for the fall growing season of El Niño years at the La Belle station and for the fall planting season of La Niña years at the Tamiami Trail station. However, a $P \geq 0.50$ was observed during the fall growing season of all ENSO phases for one 3 -d leaching rain event with the exception of the fall growing season at the La Belle station during La Niña years, which was found to be lower and significantly different from El Niño years.

In the case of 7 - $d$ leaching rain events, $P \geq 80$ occurred only for one $7-d$ leaching rain event at the Tamiami Trail station during the fall growing season of El Niño and $\mathrm{La}$ Niña years. A $P \geq 0.50$ occurred during the fall planting seasons of all ENSO phases and was found to be not significantly different. A $P \geq 0.50$ also occurred for all growing seasons of El Niño years except for the winter growing season in Plant City and winter and spring growing seasons both at the La Belle and Tamiami Trail stations. With the exception of one 3-d event at the La Belle station, probabilities of exceedance for one single event of either 3- or 7-d 
Table 4. Probability of exceedance of having at least the specified number of leaching events of 3.0 inches (76.20 mm) or more in $3 \mathrm{~d}$ and 4.0 inches $(101.60 \mathrm{~mm})$ or more in $7 \mathrm{~d}$ for the fall, winter, and spring planting seasons for different El Niñosouthern Oscillation (ENSO) phases (neutral, El Niño, and La Niña) and all years at four weather stations in Florida.

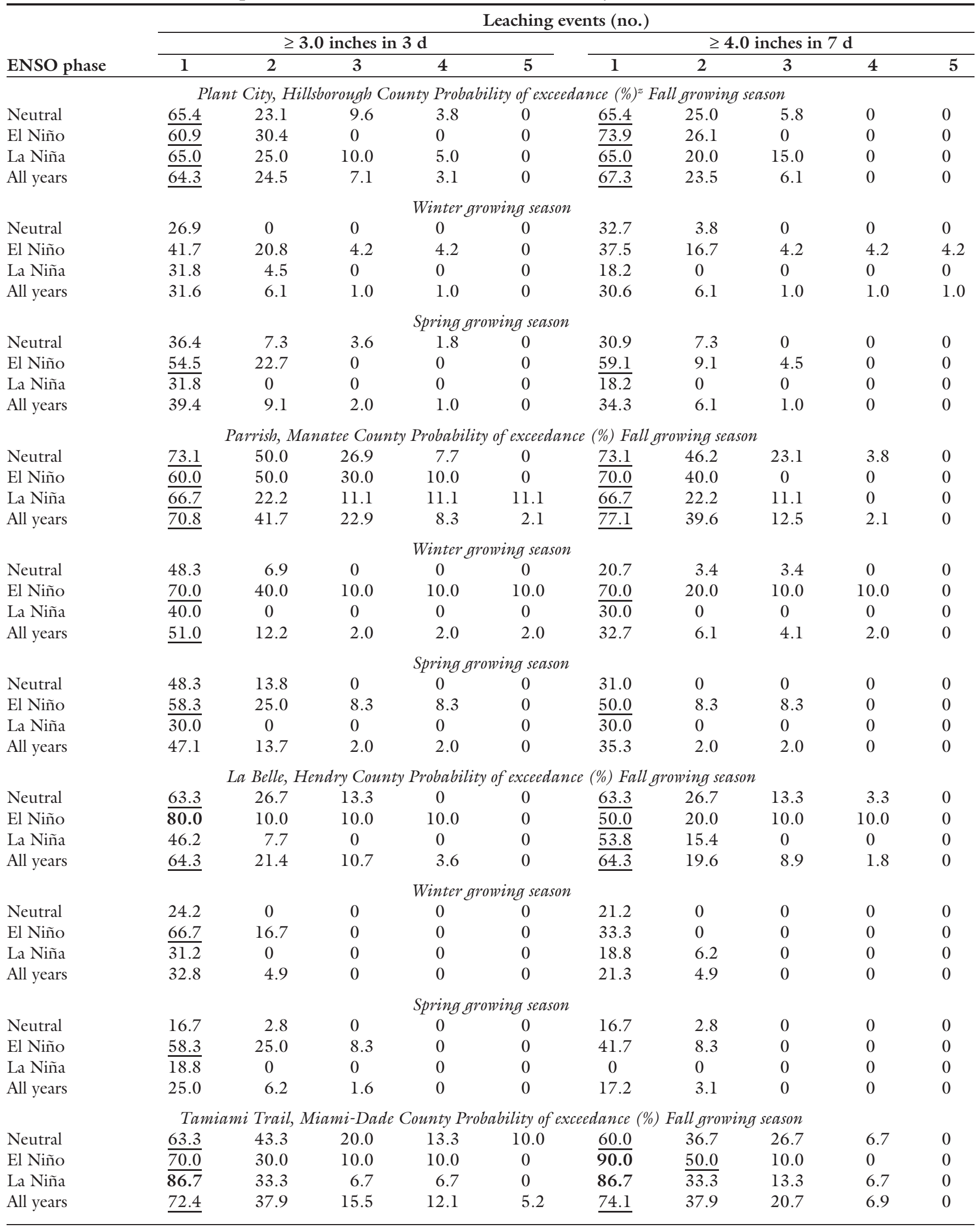


Table 4. (Continued) Probability of exceedance of having at least the specified number of leaching events of 3.0 inches (76.20 $\mathrm{mm}$ ) or more in $3 \mathrm{~d}$ and 4.0 inches $(101.60 \mathrm{~mm})$ or more in $7 \mathrm{~d}$ for the fall, winter, and spring planting seasons for different El Niño-southern Oscillation (ENSO) phases (neutral, El Niño, and La Niña) and all years at four weather stations in Florida.

\begin{tabular}{|c|c|c|c|c|c|c|c|c|c|c|}
\hline \multirow[b]{3}{*}{ ENSO phase } & \multicolumn{10}{|c|}{ Leaching events (no.) } \\
\hline & \multicolumn{5}{|c|}{$\geq 3.0$ inches in $3 \mathrm{~d}$} & \multicolumn{5}{|c|}{$\geq 4.0$ inches in $7 \mathrm{~d}$} \\
\hline & 1 & 2 & 3 & 4 & 5 & 1 & 2 & 3 & 4 & 5 \\
\hline \multicolumn{11}{|c|}{ Winter growing season } \\
\hline Neutral & 21.2 & 6.1 & 3.0 & 0 & 0 & 15.2 & 6.1 & 3.0 & 0 & 0 \\
\hline El Niño & 30.8 & 7.7 & 0 & 0 & 0 & 30.8 & 7.7 & 0 & 0 & 0 \\
\hline La Niña & 31.2 & 6.2 & 0 & 0 & 0 & 18.8 & 6.2 & 0 & 0 & 0 \\
\hline \multicolumn{11}{|c|}{ Spring growing season } \\
\hline Neutral & 12.9 & 3.2 & 0 & 0 & 0 & 3.2 & 0 & 0 & 0 & 0 \\
\hline El Niño & 33.3 & 8.3 & 8.3 & 0 & 0 & 33.3 & 0 & 0 & 0 & 0 \\
\hline La Niña & 0 & 0 & 0 & 0 & 0 & 0 & 0 & 0 & 0 & 0 \\
\hline All years & 13.6 & 3.4 & 1.7 & 0 & 0 & 8.5 & 0 & 0 & 0 & 0 \\
\hline
\end{tabular}

${ }^{2}$ Probabilities of exceedance $P \geq 0.80$ are in bold and $0.80>P \geq 0.50$ are underlined.

leaching rainfalls were found not to be significantly different during $\mathrm{El}$ Niño and La Niña years and mostly less than 0.80 . These results provide little justification for adjusting fertilizer applications for 3- and 7-d rainfall events based on ENSO phases and environmental risk levels selected ( $P=$ 1.00 and $>0.80)$. However, from a business risk standpoint $(P>0.50)$, these results would justify higher fertilizer rates during the fall growing season of all years and the winter and spring growing seasons of $\mathrm{El} \mathrm{Niño}$ years.

Economic Assessment. Based on the results obtained for 1 -d leaching rainfall events and the supplemental fertilizer application allowed in the UF-IFAS fertilizer recommendations and BMPs, supplemental fertilizer applications are expected to vary depending on the selected probability threshold and location, ranging from 0 to $30 \mathrm{lb} /$ acre $\mathrm{N}$ and 0 to $16.6 \mathrm{lb} /$ acre $\mathrm{K}$ for $P=1.00$ to 60 to $180 \mathrm{lb} /$ acre $\mathrm{N}$ and 33 to $100 \mathrm{lb} /$ acre $\mathrm{K}$ for $P>0.50$ (Table 5). One supplemental fertilizer application of 30 and $\mathbf{1 6 . 6}$ $\mathrm{lb} /$ acre $\mathrm{N}$ and $\mathrm{K}$, respectively, requires 88 and $29 \mathrm{lb} /$ acre ammonium nitrate and potassium sulfate at a current fertilizer cost of $\$ 30 /$ acre and $\$ 19 /$ acre, respectively. Assuming an application cost of $\$ 6 /$ acre, one supplemental application costs $\$ 55 /$ acre $(\$ 30+\$ 19+\$ 6)$. Based on current typical tomato marketable yields (2500 25-lb box/acre) and a median wholesale price of $\$ 12$ per 25 -lb box, it takes approximately a yield increase of 4.525 -lb boxes per acre (or greater than $0.2 \%$ in yield increase) to offset the cost of one supplemental fertilizer application. It is unlikely that research trials will be able to detect such small yield differences (Simonne et al., 2007). These results support the economical approach that "a small increase in fertilizer rates is a cheap insurance" against potential nutrient shortage.

\section{Conclusion}

The overall goal of the BMPs is to improve the water quality of impaired water bodies in Florida. The notion of allowing supplemental fertilizer application in case of a leaching rain is an implicit acceptance that leaching caused by rainfall may be inevitable. However, in a production system like seepage-irrigated tomato where all the fertilizer is applied preplant, it is likely that the amount of nutrient loss depends not only on the amount of rain in a leaching event, but also at what time of the season the rainfall occurs (Marlowe et al., 1983). In their strict definition, supplemental fertilizer applications are to be made after a leaching rainfall event, not as a preventive measure. $\mathrm{Al}$ though this restriction may be practical when drip irrigation is available or for small plantings (in both cases, the supplemental application may be done on an as-needed basis), punching fertilizer through the plastic mulch may take several days in large plantings, thereby replacing the environmental risk with the risk of temporary fertilizer shortage and reduced productivity. Even with the recent increase in fertilizer prices, these results suggest that increasing fertilizer applications as an attempt to compensate for the effect of leaching rains is a practice that makes economical sense, even if its impact on water quality is not fully known. Our results also suggest that in some season/ ENSO phase combinations, the historical probability of leaching rainfall was high enough (4 years out of 5 ) to warrant "preventive" applications done at the time of bedding. Additional BMPs such as off-season field flooding, trapping residual nutrients with cover crops, using controlledrelease fertilizer sources, or treating nutrient discharges in detention/ retention areas could be used to mitigate the environmental impact of vegetable production (FDACS, 2005). It is also important to recognize that nutrient leaching is not only a function of rainfall amount and intensity, but also of other important factors such as soil type, antecedent water table level, and drainage volume and rate.

The practical applicability of these results should be assessed in the context of three limitations. First, the probabilities of exceedance presented were based on historical ENSO phases. This means that either based on forecast or on actual verification during or shortly after the event, the ENSO phase was confirmed. In real life, growers can only rely on the predictions of the ENSO phases and need to make fertilizer decisions before or during the growing season, not after. The assessment and discussion of these predictions 
Table 5. Range of leaching rainfall events and corresponding supplemental fertilizer applications to tomato grown with plasticulture and seepage irrigation in southern Florida according to long-term probabilistic thresholds.

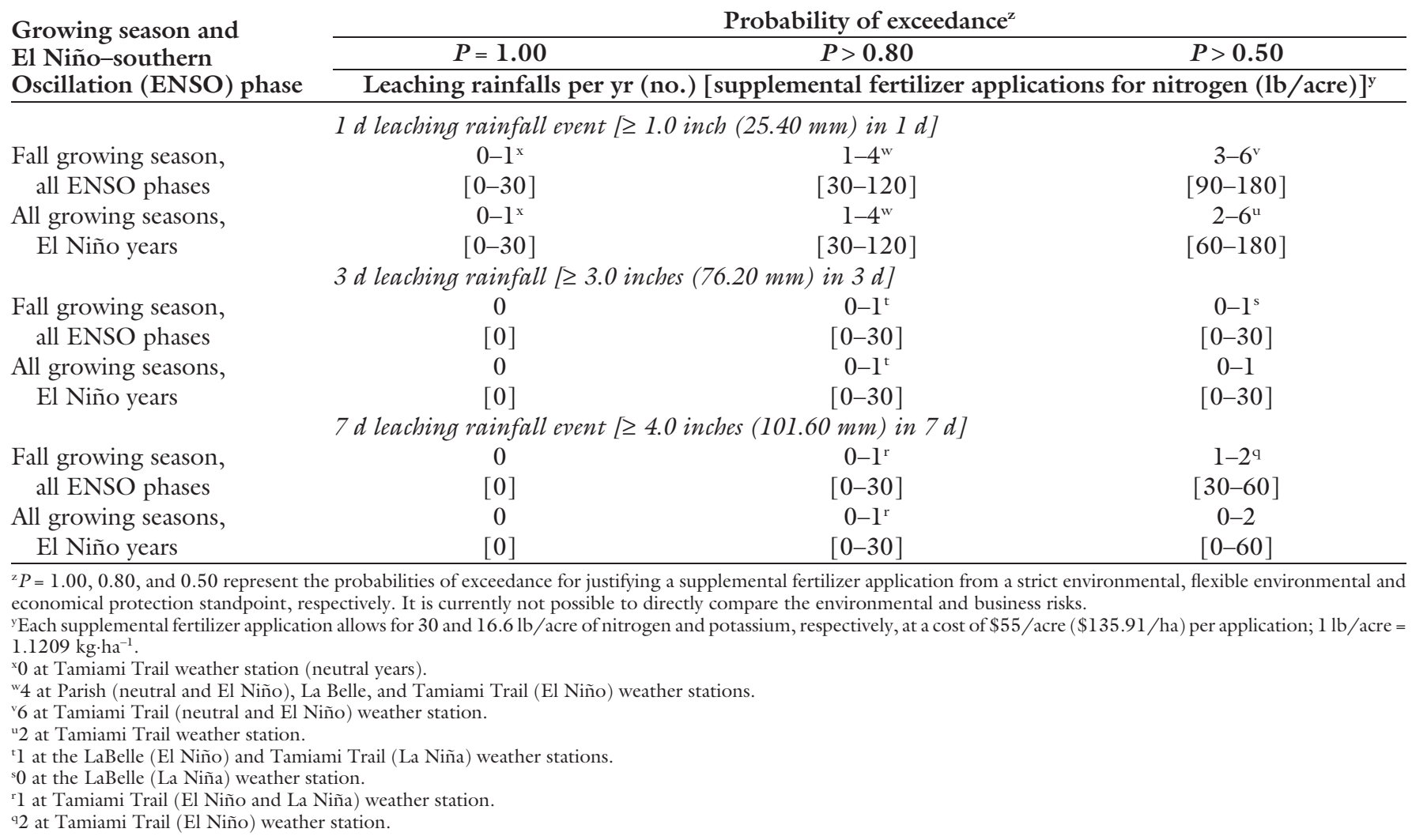

were beyond the scope of this study. Hence, because there were no production drawbacks in using fertilizer rates above those currently recommended and the price of fertilizers was low, it was a good risk management strategy to be prepared for a "frequent El Niño year." The validity of this strategy may change based on environmental regulations and increases in fertilizer costs. Second, probabilities of exceedance represent a long-term probability and should not be strictly interpreted. For example, $P=0.80$ represents a 4 out of 5-year long-term probability, and not 4 out of 5 consecutive years. Third, systematically applying the probabilities of exceedance based on a weather station to an entire county would ignore the spatial variability of rainfall in Florida. Baigorria et al. (2007) analyzed the spatial variability of rainfall in the southeastern United States using both daily and monthly rainfall data. They concluded that two well-defined rainfall spatial correlation patterns were found corresponding to the frontal and the convective rainy seasons. Spatial correlations during the frontal rainy season were characterized by a widely spread pattern in a northeast-southwest direction around weather stations, which is perpendicular to the usual weather front paths. During the convective rainy season, correlations were characterized by small concentric patterns in which correlations decreased rapidly over short distances from each weather station. However, larger areas of higher correlations were found using monthly rainfall amounts than when using daily rainfall amounts. Because tomato growing seasons of interest are concentrated during the period of time when rainfall is primarily originated from the passage of low-pressure systems and not from convection, we can expect increased spatial correlation around weather stations to facilitate the implementation of the proposed fertilizer adjustment system. Hence, the methodology used in this study can be applied to create maps of "leaching risk" probabilities that could eventually be used for adjusting fertilizer recommendations. Growers with historical data from their own weather stations could recalculate site-specific probabilities of exceedance before making management decisions.

\section{Literature cited}

Baigorria, G.A., J.W. Jones, and J.J. O'Brien. 2007. Understanding rainfall spatial variability in southeast USA at different timescales. Intl. J. Climatol. 27:749-760.

Black, R.J. 1993. Florida climate data. Univ. Florida, Inst. Food Agr. Sci., Florida Coop. Ext. Serv. Circ. EES-5.

Cantliffe, D., P. Gilreath, D. Haman, C. Hutchinson, Y. Li, G. McAvoy, K. Migliaccio, T. Olczyk, S. Olson, D. Parmenter, B. Santos, S. Shukla, E. Simonne, C. Stanley, and A. Whidden. 2006. Review of nutrient management systems for Florida vegetable producers. Proc. Florida State Hort. Soc. 119:240-248.

Daniel, W.W. 1995. Biostatistics: A foundation for analysis in the health sciences. Wiley, New York, NY.

Florida Department of Agriculture and Consumer Services. 2005. Water quality/quantity best management practices for Florida vegetable and agronomic crops. 10 July 2008. <http:// www.floridaagwaterpolicy.com/PDF/ Bmps/Bmp_VeggieAgroCrops2005.pdfs.

Florida Department of Agriculture and Consumer Services. 2008. Florida 
agriculture statistical directory. 10 Dec. 2008. <http://www.florida-agriculture.$\mathrm{com} /$ pubs/pubform/pdf/Florida_Agricultural_Statistical_Directory.pdf $>$.

Fraisse, C.W., N.E. Breuer, D. Zierden, J.G. Bellow, J. Paz, V.E. Cabrera, A. Garcia y Garcia, K.T. Ingram, U. Hatch, G. Hoogenboom, J.W. Jones, and J.J. O'Brien. 2006. AgClimate: A climate forecast information system for agricultural risk management in the southeastern USA. Comput. Electron. Agr. 53:13-27.

Fraisse, C.W., D. Zierden, N.E. Breuer, and J. Jackson. 2004. Climate forecast and decision making in agriculture. Univ. Florida, Inst. Food Agr. Sci., Circ. AE267. 15 Aug. 2008. <http://edis. ifas.ufl.edu/AE267>.

Hanley, D.E., M.A. Bourassa, J.J. O'Brien, S.R. Smith, and E.R. Spade. 2003. A quantitative evaluation of ENSO indices. J. Clim. 16:1249-1258.

Hansen, J.W., J.W. Jones, C.F. Kiker, and A.W. Hodges. 1999. El Niño-southern oscillation impacts on winter vegetable production in Florida. J. Clim. 12:92-102.

Hendricks, G.S., S. Shukla, K.E. Cushman, T.A. Obreza, F.M. Roka, K.M. Portier, and E.J. McAvoy. 2007. Florida watermelon production affected by water and nutrient management. Hort Technology 17:328-335.

Jaber, F.H. and S. Shukla. 2006. Effects of spoil moisture sensor spacing and zone of influence on recharge calculation. Soil Sci. 171:305-312.

Keating, B.A., P.S. Carberry, G.L. Hammer, M.E. Probert, M.J. Robertson, D. Holzworth, N.I. Huth, J.N.G.
Hargreaves, H. Meinke, Z. Hochman, G. McLean, K. Verburg, V. Snow, J.P. Dimes, M. Silburn, E. Wang, S. Brown, K.L. Bristow, S. Asseng, S. Chapman, R.L. McCown, D.M. Freebairn, and C.J. Smith. 2003. An overview of APSIM, a model designed for farming systems simulation. Eur. J. Agron. 18:267-288.

Marlowe, G.A., Jr., P.R. Gilreath, and R.J. Wilder. 1983. Leaching losses and fertilizer replenishment of full bed mulched tomatoes. Univ. Florida, Inst. Food Agr. Sci., Proc. Florida Tomato Inst. Publ. VEC 83-3.

Olson, S.M. and E.H. Simonne. 2007. Vegetable production handbook for Florida. Vance, Lenexa, KS.

Olson, S.M., W.M. Stall, M.T. Momol, S.E. Webb, T.G. Taylor, S.A. Smith, E.H. Simonne, and E. McAvoy. 2007. Tomato production in Florida. Univ. Florida, Inst. Food Agr. Sci. HS 739. 25 Nov. 2008. $<$ http://edis.ifas.ufl.edu/CV137>.

Ozores-Hampton, M.P., E. Simonne, E. McAvoy, P. Stansly, S. Shukla, P. Roberts, F. Roka, T. Obreza, K. Cushman, P. Gilreath, and D. Parmenter. 2006. Nitrogen BMP efforts with tomato production in Florida: Update for 2005-2006 season. Proc. Florida State Hort. Soc. 119:284288.

Rao, R. and Y. Li. 2003. Management of flooding effects on growth of vegetable and selected field crops. Hort Technology 13:610-616.

Rosenzweig, C. and D. Hillel. 2008. Climate variability and the global harvest. Oxford University Press, New York, NY.
Simonne, E.H. and G.J. Hochmuth. 2007. Soil and fertilizer management for vegetable production in Florida, p. 3-15. In: S.M. Olson and E.H. Simonne (eds.). Vegetable production handbook for Florida 2007. Univ. Florida, Inst. Food Agr. Sci., Gainesville, FL.

Simonne, E.H., M. Ozores-Hampton, R. Little, K. Cushman, F. Roka, P. Stansly, S. Shukla, P. Roberts, K. Morgan, T. Obreza, G. McAvoy, P. Gilreath, and D. Parmenter. 2007. Power analysis of onfarm fertilizer trials with tomato. Proc. Florida State Hort. Soc. 120:191-196.

Smajstrla, A.G., D.S. Harrison, D.Z. Haman, and F.S. Zazueta. 1992. Irrigated acreage in Florida. Florida Coop. Ext. Serv. Circ. 1030.

Southeast Climate Consortium. 2008. AgroClimate: A service of the Southeast Climate Consortium. 29 Dec. 2008. <http://www.agroclimate.org>.

Tritel, H. 2005. Understanding and forecasting ENSO. 20 Aug. 2008. <http:// www.ncdc.noaa.gov/oa/rsad/ ElNinoresearchpaper.pdf>.

Wang, E., J.H. Xu, and C.J. Smith. 2008. Value of historical climate knowledge, SOI-based seasonal climate forecasting and stored soil moisture at sowing in crop nitrogen management in southeastern Australia. Agr. For. Meteorol. 148:17431753.

Winsberg, M.D. 2003. Florida weather. University Press of Florida, Gainesville, FL. 